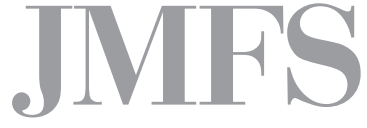

Journal of Management and Financial Sciences
Volume XIII

Issue 35 (December 2018

pp. $25-40$

Warsaw School of Economics

Collegium of Management and Finance

Iwona Franczak

Department of Accounting

Faculty of Finance and Insurance

University of Economics in Katowice

\title{
Local government finance assessment on the basis of budget implementation statements
}

\begin{abstract}
This article discusses local government finances in Poland and the scope of budget implementation statements taking into consideration literature analysis and regulation interpretation. In proving the research hypothesis as being valid, the project confirms that budget implementation statements of local governments give rise to the formation of judgements regarding said local government finances. Toward this end, the study assessments have quantitative values initially based on basic descriptive statistics, further developed through the application of Pearson's correlation coefficient and Spearman's rank-order correlation coefficient.
\end{abstract}

Keywords: budget implementation statement, local government finances JEL Classification Codes: H720, M41 


\section{Introduction}

The reporting of local government units (LGU) involves the collection and organization of data reflecting the processes of generating and disbursing public funds. This reported data is not only an indispensable source of information for assessing revenue generation and budget spending with regard to various timeframes, but also serves to insure proper execution of LGU budgets. The level and structure of LGU budget expenditures testifies to the degree of decentralization of the public finance system, as well as demonstrates the position of local governments in performing public tasks. The expenditures of LGUs serve to fulfill the objectives and tasks defined in a local unit's development strategy, which are the political expression of the said authority regarding social and economic objectives.

The objective of the article is a study of debt impact on revenue levels and growth thereof in a class of Poland's districts (i.e. 'powiat' in Polish) - excluding the cities having the district classification - on the basis of data gathered from budget implementation statements for the years 2014-2016, inclusive. The hypothesis that powiat districts, excluding the cities having the powiat classification, with higher debt levels for 2014-16, also showed higher investment expenditures and faster revenue growth than those districts showing low debt levels, again excluding the cities with the district classification will be verified. Toward this end various volume characteristics will be examined. In order to characterize various variable structures, fundamental descriptive statistics will be generated and confirmed by Pearson's linear correlation coefficient and Spearman's correlation ranking. The employed research methods include literature and legislative analyses and statistical inference.

\section{Local government finance}

The Constitution of the Republic of Poland [Dz. U.1997 (Journal of Laws) No. 78, Item 483] assures LGUs' participation in public revenues at levels respective of their mandates. Article 167 of Poland's Constitution identifies three sources of revenue: own-source, general subsidies and targeted grants issued from the state's budget. Detailed regulations are included in laws defining governmental systems and mandates for communes (i.e. 'gmina' in Polish), [Law of March 8, 1990 regarding Commune Government, Dz. U. 2017 (Journal of Laws), Item 1875], districts (i.e. 'powiat'), [Law of June 5, 1998 regarding District Government, Dz. U. 2017, 9Journal of Laws), item 1868] or voivodships [Law of June 5, 1998 regarding Voivodship Government, Dz. U. 2017 (Journal of Laws), Item 2096]. The basis of independent finance for these local government units is their budget. A local government's properly planned budget should function as a key instrument in management and planning processes.

The main activity of LGUs' budget management is keeping track of funds, as in recording capital turnover through government banking accounts resulting from generated revenue; 
budget expenditures by subordinate offices; receiving subsidies, grants and allocations of the state's income tax; revenues collected by tax authorities for LGUs; as well as other revenues, and received credits and loans [Winiarska, Kaczurak-Kozak, 2013, p. 100]. In contrast to entities set on generating profits, a local government unit measures its effectiveness on the basis of community satisfaction - not on the accounting data of revenues and expenditures. On the other hand, the LGU possesses autonomy extending into finances. Two aspects of this autonomy can be highlighted - revenues and expenditures [Staszel, 2016, pp. 65-80]. LGUs' revenue sources and how they are established have been defined in Chapter 2, of the Law of November 13, 2003 regarding Local Government Revenues (LGR) [Dz. U. 2017, (Journal of Laws), Item 1453]. Local government unit revenues are:

- own-source revenue from taxes and local service charges, revenue gained from LGU budgetary entities, including payments by public sector entities, revenue from LGU assets, inheritance, behests, donations to LGUs, allotments from state income taxes from individuals and commercial interests;

- general subsidies, and

- targeted grants from the national budget [Law of November 13, 2003 regarding Local Government Revenues, Art. 3, No. 1].

LGR can also originate from:

- foreign capital not subject to repayment;

- capital from the European Union budget, and

- other sources defined in separate legislation [Law of November 13, 2003 regarding Local Government Revenues, Art. 3, No. 3].

Each LGU, in enabling the established policy, strives to gain a competitive advantage with regard to attracting investments; but not only, as the community's quality of life is also important. Securing entrepreneurs and new commercial constructions directly translates into greater revenues for the said district - especially own-source revenues - which can then finance tasks serving development stimulation [Filipiak, 2017, pp. 95-105].

In the LGU budget revenue schedule, anticipated current revenues and property revenues are itemized according to their source. Property Revenues include [Law of August 27, 2009 regarding Public Finance, Dz. U. 2017 (Journal of Laws), Item 2077, Art. 235]:

- subsidies and means intended for investments;

- revenue from property sales, and

- revenue from converting perpetual usufruct to ownership.

Clarification of current revenues is specified by a negative definition in Article 235, Paragraph 2, of the public finance law 'as budget revenue not being property revenue' [Law of August 27, 2009 regarding Public Finance, Art. 235].

Expenditures incurred by LGUs are tied into task performance as defined by law. Making expenditures is part of the process whose first phase requires collecting revenues for performing essential tasks, which in turn require spending money [Mastalski, Fojcik-Mastalska, 2013, p. 479]. The normative expenditure classification results from the public finance 
law where LGU expenditure classification is undertaken in two places: Article 216 divides expenditures according to tasks and their performance for which capital is earmarked, and again in Article 236, where types of expenditures are tied to line-items in an LGU's budget spending schedule.

The legislature, in Article 236 of the public finance law, defines property expenditures by specifically indicating their purpose, whereas in reference to current expenditures, it again applies a a negative definition, i.e. all expenditures not being property expenditures are current expenditures [Mastalski, Fojcik-Mastalska, 2013, p. 481]. On the basis of the public finance law, establishing a finite catalogue of current expenditures is not possible, yet the law's provisions indicate the need for detailed itemization in the current expenditure schedule by type, especially:

- budgetary entity expenditures including salaries and premiums based thereon and expenditures tied to performing statutory tasks;

- grants for current tasks;

- benefits for individuals;

- expenditures for programmes funded in part as defined in Article 5, Paragraph 1, Items 2 and 3 of the public finance law regarding statutory services of LGUs;

- disbursements based on issued warrants and guarantees by an LGU, assessed as due in a given budget year, and

- expenditures for servicing LGU debt [Law of August 27, 2009 regarding Public Finance, Art. 236, Par. 3].

Property expenditures include:

- investments and investment purchasing for programmes funded in part as defined in Article 5, Paragraph 1, Items 2 and 3 of the public finance law regarding statutory services of LGUs;

- purchase and control of stocks and shares, and

- payment of contributions to commercial enterprises [Law of August 27, 2009 regarding Public Finance, Art. 236, Par. 4].

In the LGU budget expenditure schedule, current and property expenditure amounts are itemized according to sections and sub-section classifications [Winiarska, Kaczurak-Kozak, 2013, p. 112].

Article 89 of the public finance law allows taking advantage of repayable sources of finance by LGUs under strictly defined conditions for purposes of:

- covering LGU temporary deficits during the yearly budget, resulting from incidental financial shortages caused by timely unspent revenues;

- financing anticipated LGU budget deficits which are tied to undertaken expenditures not covered in planned revenues;

- paying off earlier taken obligations resulting from issued securities, contracted loans and credits, and

- advance financing of funds from contracted future sources within the EU budget. 


\section{Budget implementation statement of local government units}

The LGU budget may enhance the rationality of a unit's activity. To know to which area a local government allocates budgetary funding is valuable information regarding an LGU's developmental direction for numerous stakeholders - management, local residents, and commercial interests in the said jurisdiction [Owsiak, 2002, p. 32].

The reporting of public finance sector units includes summary tables presenting the processes of generating and distributing public funds. The reporting budget data is based on accounting. This information is an essential source for determining revenue levels and budgetary expenditures in various time frames and monitoring competent budget execution during and after the budget year [Bogucka-Felczak, 2017, pp. 77-90].

The budget implementation statement of an LGU demonstrates statute fulfillment of Article 261, Paragraph 1, Item 1 and Paragraph 3 of the public finance law under which the LGU presents the overseeing authority and the Regional Accounting Chambers with documentation that it has in fact implemented its budget. In accordance with Article 247 of the public finance law, the executive board of an LGU is responsible for realizing its budget. Regarding the various levels of local government administration, the executive board is the Implementation Body for the said unit, i.e. the wójt, burmistrz, mayor, district and voivodship executive boards. The annual statement regarding budget completion by the LGU's executive, in accordance with Article 267, Paragraph 1, Item 1 of the public finance law, shall be drawn up and presented to appropriate oversight authorities by March 31 of the following budget year.

The statement regarding the completed budget contains a listing of revenues and expenditures based on closed accounts in the LGU budget at not lower figures than at budget approval, and based on budget accounting ledgers [Miemiec et al., 2013, p. 242]. The instrumental function of the statement is delivering detailed data and information upon which an assessment of LGU budget execution can be made [Adamek-Hyska, 2016, pp. 28-38]. The statement should include:

1. revenues and expenditures of the LGU budget in an as detailed form as the budget approval;

2. amendments to the expenditure schedule of completed financial programmes from funds as defined in Article 5 - 'Concept of Public Funds and Public Revenues' - Paragraph 1, Items 2 and 3 of the public finance law, and transacted in a given budget year, and

3. the advancement stage of multi-year programmes [Law of August 27, 2009 regarding Public Finance, Art. 269].

In the annual statement, the executive board should not only restrict itself to presenting revenues and expenditures, but also showing budget results and the indebtedness of the unit as of the end of the budget year [Miemiec et al., 2013, p. 243]. In practice the LGU budget implementation statement consists of tables of earmarked sums and source-detailed received revenues and categorized budget classifications, divided into current and property revenues, as well as current and property disbursements. The statement also presents the budget's balance 
- revenues vs. expenditures, indebtedness and explanations of the above [Adamek-Hyska, 2016, pp. 28-38].

In Article 267 of the public finance law, it appears that the statement also includes a listing of budgetary entities as discussed in Article 223 of the same law - 'Revenues of Local Government Unit Entities Operating Commercially as per the Law; Educational Corporation'. The LGU's executive board also files, to March 31 of the following budget year, besides the implementation statement:

1. a statement as defined in Article 265, Item 2, of the public finance law;

2. an inventory of assets addressing -

a. data pertaining to asset ownership;

b. data pertaining to:

i. other than ownership but controlling interests such as perpetual usufruct, receivables, participation in corporations, shares;

ii. possession;

c. data regarding status changes in communal properties as defined in a. and b. above, as of the date of status change;

d. data regarding received revenues by execution of property rights, other property laws and executed possession, and

e. other data and information of events having an impact on LGU asset conditions [Law of August 27, 2009 regarding Public Finance, Art. 267].

A properly generated LGU budget implementation statement, with attached financial reports becomes the starting point for assessing the activity of the said unit for the past budget year, which has an impact on discharge approval [Błaszko, et al., 2015, p. 164].

\section{Correlative analysis of district commitments with revenue levels for 2014-2016 excluding the cities having the district classification}

In all the collective tables below, the data is based on annual reports received by Poland's Ministry of Finance from local government units including budgetary entities, LGU budgetary enterprises, and revenue and expenditure receipts as listed in Article 223, Paragraph 1 of the public finance law. Because this article's reference is restricted, the primary data source were district (powiat) budget implementation statements for the years 2014-2016 (inclusive), with the exception of the cities with the district classification. The powiat district is essentially superimposed onto local government units, and as such should be complementary and stabilizing to the smaller commune (gmina) administrative entity. Transferring certain tasks to the voivodship level would result is distancing the said tasks from the local community. The district entity fills this gap. The study excludes the cities with the district classification, which in effect are communes with the city status performing district tasks. It has been accepted that 
cities of district status are not districts per se, but communes authorized by the state to fulfill a broadened range of tasks. The years 2014-16 underwent the analysis with the intent of examining the relationships' tendencies after full year reporting.

The objective of the study was to verify the following hypothesis: districts (excluding the cities with the district classification) which showed higher obligations in 2014 to 2016, also showed higher investment expenditures and faster revenue growth than those districts (same exclusion) whose obligations were low. ${ }^{1}$

In studying the evaluations, the characteristics were assigned quantitative values. With structure characterization in mind, the studied variables were calculated using basic descriptive statistics for the measures of location, variability, asymmetry and concentration [Kończak, Trzpiot, 2014, pp. 239-244].

In order to confirm the relationship validity between variables, Pearson's correlation coefficient for linear vectors was calculated, as was Spearman's rank-order correlation coefficient, and point spread plotted using regression functions. All the graphs reflect the materiality significance level equal to 0.05 . In order to analyze the selected variables, the primary statistical measures were established. For determining the correlation between all the studied characteristics, a variable matrix was generated. To establish statistical significance of individual explanatory variables $(\mathrm{X})$ relative to the dependent variable $(\mathrm{Y})$, correlation vectors were established.

The analysis of the study results began with the calculation of the basic descriptive statistics as measurements of position, variability, asymmetry and concentration for the analyzed variables. Additional delta variables were included to record the activity dynamics from year- to-year (Table 1).

The data analysis indicates wide variations in the examined variables. In a majority of variables the coefficient of variation was greater than $20 \%$. The asymmetry coefficient also indicates that among the majority of variables, there were extreme distortions - left and right; and the coefficient of concentration indicated strong concentrations around the Kurtoza Average in several cases. After completing the analysis of the basic descriptive variables, correlation analysis was undertaken with the intention of proving the proposed dependency of total expenditures dynamics - including investment expenditures to obligation levels and dynamic dependency of total revenues - including own-source to obligation levels (Table 2).

1 This study is an extension of studies performed, among others, by J. Wojciechowski, 'Wpływ zadłużenia na kształtowanie się dochodów oraz wydatków gmin miejskich województwa kujawsko-pomorskiego w latach 1993-2006', Rocznik Żyrardowski, Vol. 6, http://mazowsze.hist.pl/files/Rocznik_Zyrardowski/PDF_bez_tytulowych/Rocznik_ Zyrardowski-r2008-t6/Rocznik_Zyrardowski-r2008-t6-s165-200/Rocznik_Zyrardowski-r2008-t6-s165-200.pdf 
Table 1. Basic descriptive statistics

\begin{tabular}{|c|c|c|c|c|c|c|c|c|}
\hline & 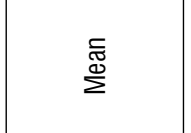 & 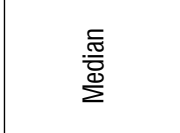 & $\dot{\sum}$ & 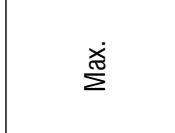 & 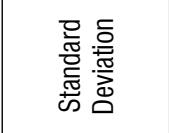 & 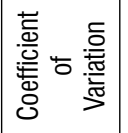 & 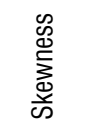 & $\begin{array}{l}\frac{\infty}{10} \\
\frac{0}{5} \\
\frac{1}{3}\end{array}$ \\
\hline $\begin{array}{l}\text { Total Revenue [PLN] } \\
2014\end{array}$ & 965.34 & 947.10 & 507 & 1942 & 211 & 21.86 & 1.03 & 2.80 \\
\hline $\begin{array}{l}\text { Total Revenue [PLN] } \\
2015\end{array}$ & 960.13 & 941.42 & 480 & 1913 & 197 & 20.50 & 0.92 & 2.62 \\
\hline $\begin{array}{l}\text { Total Revenue [PLN] } \\
2016\end{array}$ & 965.28 & 951.23 & 553 & 1678 & 179 & 18.50 & 0.53 & 1.22 \\
\hline $\begin{array}{l}\text { Delta Total Revenue } \\
\text { 2015-2014 }\end{array}$ & -5.21 & -3.25 & -351 & 349 & 77 & -1479.20 & -0.07 & 3.36 \\
\hline $\begin{array}{l}\text { Delta Total Revenue } \\
\text { 2016-2015 }\end{array}$ & 5.15 & 17.26 & -612 & 260 & 88 & 1703.96 & -2.83 & 16.80 \\
\hline $\begin{array}{l}\text { Delta Total Revenue } \\
\text { 2016-2014 }\end{array}$ & -0.063 & 14.65 & -796 & 251.2 & 98.86 & -157639 & -2.76 & 16.13 \\
\hline $\begin{array}{l}\text { Own-source } \\
\text { Revenue [zł] } 2014\end{array}$ & 283.74 & 265.68 & 134 & 670 & 83 & 29.25 & 1.70 & 4.51 \\
\hline $\begin{array}{l}\text { Own-source } \\
\text { Revenue [PLN] } 2015\end{array}$ & 302.47 & 286.58 & 155 & 665 & 80 & 26.45 & 1.18 & 2.39 \\
\hline \begin{tabular}{|l} 
Own-source \\
Revenue [PLN] 2016
\end{tabular} & 322.07 & 303.41 & 156 & 726 & 86 & 26.60 & 1.24 & 2.70 \\
\hline \begin{tabular}{|l|} 
Delta Own-source \\
Revenue 2015-2014
\end{tabular} & 18.73 & 19.29 & -228 & 148 & 31 & 167.58 & -2.15 & 17.57 \\
\hline \begin{tabular}{|l} 
Delta Own-source \\
Revenue 2016-2015
\end{tabular} & 19.60 & 17.86 & -92 & 311 & 33 & 166.02 & 2.62 & 24.00 \\
\hline $\begin{array}{l}\text { Delta Own-source } \\
\text { Revenue 2016-2014 }\end{array}$ & 38.32 & 37.66 & -244 & 313 & 41 & 105.98 & -0.64 & 17.78 \\
\hline $\begin{array}{l}\text { Total Population } \\
2014\end{array}$ & $82,314.31$ & $73,035.00$ & 20,778 & 35,8894 & 42,629 & 51.79 & 1.90 & 6.63 \\
\hline \begin{tabular}{|l} 
Total Population \\
2015 \\
\end{tabular} & $82,220.60$ & $72,839.00$ & 20,606 & 366,037 & 42,977 & 52.27 & 1.95 & 7.08 \\
\hline $\begin{array}{l}\text { Total Population } \\
2016\end{array}$ & $82,251.38$ & $72,637.00$ & 20,417 & 373,570 & 43,364 & 52.72 & 2.00 & 7.52 \\
\hline $\begin{array}{l}\text { Total Expenditures } \\
\text { [PLN] } 2014\end{array}$ & $75,746,184.78$ & $69,551,146.63$ & $21,060,824$ & $223,466,439$ & $32,277,889$ & 42.61 & 1.00 & 1.19 \\
\hline $\begin{array}{l}\text { Total Expenditures } \\
\text { [PLN] } 2015 \\
\end{array}$ & 74662760.10 & $68,337,724.39$ & $16,756,218$ & $240,154,771$ & $33,058,273$ & 44.28 & 1.25 & 2.27 \\
\hline $\begin{array}{l}\text { Total Expenditures } \\
\text { [PLN] } 2016 \\
\end{array}$ & 74205718.54 & $67,754,956.43$ & $19,085,717$ & $250,184,646$ & $33,488,277$ & 45.13 & 1.36 & 3.10 \\
\hline $\begin{array}{l}\text { Delta Expenditures } \\
\text { 2015-2014 }\end{array}$ & -1083425 & $-1,327,166$ & $-26,626,930$ & $43,431,548$ & $8,138,091$ & -751.15 & 1.44 & 6.81 \\
\hline $\begin{array}{l}\text { Delta Expenditures } \\
2016-2015\end{array}$ & -457042 & 289,827 & $-57,891,830$ & $22,556,010$ & $9,026,459$ & -1974.98 & -2.87 & 15.64 \\
\hline $\begin{array}{l}\text { Delta Expenditures } \\
2016-2014\end{array}$ & $-1,540,466$ & $-1,039,497$ & $-38,511,303$ & $33,296,524$ & $8,344,344$ & -541.68 & -0.19 & 3.32 \\
\hline $\begin{array}{l}\text { Assets, Investment } \\
\text { Expenditures [PLN] } \\
2014\end{array}$ & $10,974,908.77$ & $8,871,936.60$ & 40,120 & $45,974,758$ & $7,947,065$ & 72.41 & 1.51 & 2.79 \\
\hline $\begin{array}{l}\text { Assets, Investment } \\
\text { Expenditures [PLN] } \\
2015\end{array}$ & $10,776,693.07$ & $8,349,391.26$ & 256,384 & $78,942,636$ & $10,004,332$ & 92.83 & 2.24 & 15.07 \\
\hline
\end{tabular}




\begin{tabular}{|c|c|c|c|c|c|c|c|c|}
\hline & 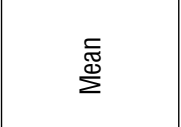 & 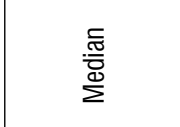 & $\dot{\sum}$ & 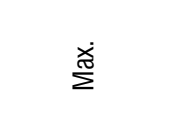 & 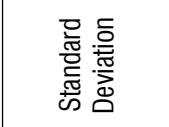 & 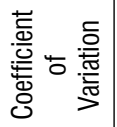 & 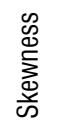 & $\begin{array}{l}\frac{\infty}{\infty} \\
\frac{0}{5} \\
\underline{y}\end{array}$ \\
\hline $\begin{array}{l}\text { Assets, Investment } \\
\text { Expenditures [PLN] } \\
2016\end{array}$ & $9,435,177.67$ & $8,028,666.59$ & 293,289 & $48,236,809$ & 7,342,092 & 77.82 & 1.76 & 4.12 \\
\hline $\begin{array}{l}\text { Total Obligations } \\
\text { [PLN] }\end{array}$ & $17,725,521.12$ & $14,177,495.72$ & 0 & $67,586,476$ & $13,685,306$ & 77.21 & 1.24 & 1.53 \\
\hline $\begin{array}{l}\text { Total Obligations per } \\
\text { Resident [PLN] }\end{array}$ & 232.43 & 202.78 & 0.00 & 948.80 & 162.46 & 69.90 & 1.08 & 1.85 \\
\hline
\end{tabular}

Source: Own elaboration on the basis of Information re: LGU Budget Implementation Statements 2014-2016, Poland's Ministry of Finance, http://www.mf.gov.pl/ministerstwofinansow/dzialalnosc/finanse-publiczne/budzety-jednostek-samorzadu-terytorialnego/ sprawozdania-budzetowe/

Table 2. Correlation [red indicates valid correlations with levels of $<0.050$ ]

\begin{tabular}{|c|c|c|c|c|}
\hline & $r(X, Y)$ & r2 & $\mathrm{t}$ & $\mathrm{p}$ \\
\hline \multicolumn{5}{|l|}{ Total Obligations [PLN] } \\
\hline Total Revenues [PLN] 2014 & 0.04 & 0.00 & 0.72 & 0.472 \\
\hline \multicolumn{5}{|l|}{ Total Obligations [PLN] } \\
\hline Total Revenues [PLN] 2015 & 0.03 & 0.00 & 0.58 & 0.562 \\
\hline \multicolumn{5}{|l|}{ Total Obligations [PLN] } \\
\hline Total Revenues [PLN] 2016 & 0.04 & 0.00 & 0.78 & 0.437 \\
\hline \multicolumn{5}{|l|}{ Total Obligations [PLN] } \\
\hline Delta Total Revenues [PLN] 2015-2014 & -0.03 & 0.00 & -0.49 & 0.625 \\
\hline \multicolumn{5}{|l|}{ Total Obligations [PLN] } \\
\hline Delta Total Revenues [PLN] 2016-2015 & 0.02 & 0.00 & 0.28 & 0.777 \\
\hline \multicolumn{5}{|l|}{ Total Obligations [PLN] } \\
\hline Delta Total Revenues [PLN] 2016-2014 & -0.007 & 0.000 & -0.13 & 0.897 \\
\hline \multicolumn{5}{|l|}{ Total Obligations [PLN] } \\
\hline Own-source Revenue [PLN] 2014 & 0.21 & 0.05 & 3.85 & 0.000 \\
\hline \multicolumn{5}{|l|}{ Total Obligations [PLN] } \\
\hline Own-source Revenue [PLN] 2015 & 0.21 & 0.04 & 3.76 & 0.000 \\
\hline \multicolumn{5}{|l|}{ Total Obligations [PLN] } \\
\hline Own-source Revenue [PLN] 2016 & 0.20 & 0.04 & 3.56 & 0.000 \\
\hline \multicolumn{5}{|l|}{ Total Obligations [PLN] } \\
\hline Delta Own-source Revenue 2015-2014 & -0.03 & 0.00 & -0.58 & 0.562 \\
\hline \multicolumn{5}{|l|}{ Total Obligations [PLN] } \\
\hline Delta Own-source Revenue 2016-2015 & 0.01 & 0.00 & 0.14 & 0.893 \\
\hline \multicolumn{5}{|l|}{ Total Obligations [PLN] } \\
\hline Delta Own-source Revenue 2016-2014 & -0.02 & 0.00 & -0.34 & 0.734 \\
\hline \multicolumn{5}{|l|}{ Total Obligations [PLN] } \\
\hline Total Expenditure [PLN] 2014 & 0.52 & 0.27 & 10.70 & 0.000 \\
\hline \multicolumn{5}{|l|}{ Total Obligations [PLN] } \\
\hline Total Expenditure [PLN] 2015 & 0.52 & 0.27 & 10.68 & 0.000 \\
\hline \multicolumn{5}{|l|}{ Total Obligations [PLN] } \\
\hline Total Expenditure [PLN] 2016 & 0.49 & 0.24 & 10.04 & 0.000 \\
\hline
\end{tabular}




\begin{tabular}{|l|c|c|c|c|}
\cline { 2 - 5 } \multicolumn{1}{c|}{} & $\mathrm{r}(\mathrm{X}, \mathrm{Y})$ & $\mathrm{r}$ & $\mathrm{t}$ & $\mathrm{p}$ \\
\hline Total Obligations [PLN] & & & & \\
\hline Delta Expenditure 2015-2014 & 0.05 & 0.00 & 0.83 & 0.409 \\
\hline Total Obligations [PLN] & & & & \\
\hline Delta Expenditure 2016-2015 & -0.06 & 0.00 & -1.07 & 0.285 \\
\hline Total Obligations [PLN] & & & & \\
\hline Delta Expenditure 2016-2014 & -0.02 & 0.00 & -0.35 & 0.725 \\
\hline Assets, Investment Expenditures [PLN] 2014 & & & & \\
\hline Total Obligations [PLN] & $\mathbf{0 . 3 1}$ & $\mathbf{0 . 0 9}$ & $\mathbf{5 . 7 0}$ & $\mathbf{0 . 0 0}$ \\
\hline Assets, Investment Expenditures [PLN] 2015 & & & & \\
\hline Total Obligations [PLN] & $\mathbf{0 . 2 5}$ & $\mathbf{0 . 0 6}$ & $\mathbf{4 . 6 4}$ & $\mathbf{0 . 0 0}$ \\
\hline Assets, Investment Expenditures [PLN] 2016 & & & & \\
\hline Total Obligations [PLN] & $\mathbf{0 . 3 1}$ & $\mathbf{0 . 1 0}$ & $\mathbf{5 . 8 2}$ & $\mathbf{0 . 0 0}$ \\
\hline
\end{tabular}

Source: Own elaboration on the basis of Information re: LGU Budget Implementation Statements 2014-2016, Poland's Ministry of Finance, http://www.mf.gov.pl/ministerstwo-finansow/dzialalnosc/finanse-publiczne/budzety-jednostek-samorzadu-terytorialnego/sprawozdania-budzetowe/

The analysis of these variables indicates that the obligation level had a positive statistical significance in the correlation with own-source revenues for 2014-2016: $\mathrm{R}(0.20-0.21)$, low correlation (Diagrams 1-3). This indicates that with higher, or rising own-source revenues, total obligations rose as well.

Analyzing the selected variables (Diagrams 4-6), one may state that the obligation level had a statistical positive correlation with general expenditures: $\mathrm{R}(0.49-0.52)$ - a strong tie. This indicates that an increase in general spending, obligations rose as well.

However, there were weak correlations between obligations and investment expenditures $\mathrm{R}(2.25-0.31)$, see diagrams 7-9. Significant correlations between obligation levels and revenue and expenditure dynamics was not indicated $-\mathrm{p}>0.05$.

\section{Diagram 1. Scatter plot: total obligations vs. own-source revenues in 2014}

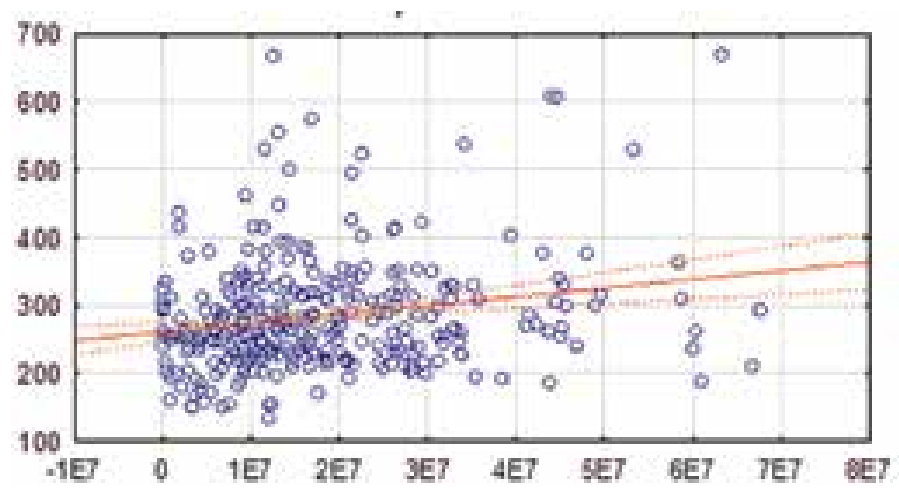

$\mathrm{X}$ - total obligations [pln], Y - own-source revenue [pln], correlation ' $r$ ' $=0.21321$

Source: Own elaboration on the basis of Table 2. 
Diagram 2. Scatter plot: total obligations vs. own-source revenues in 2015

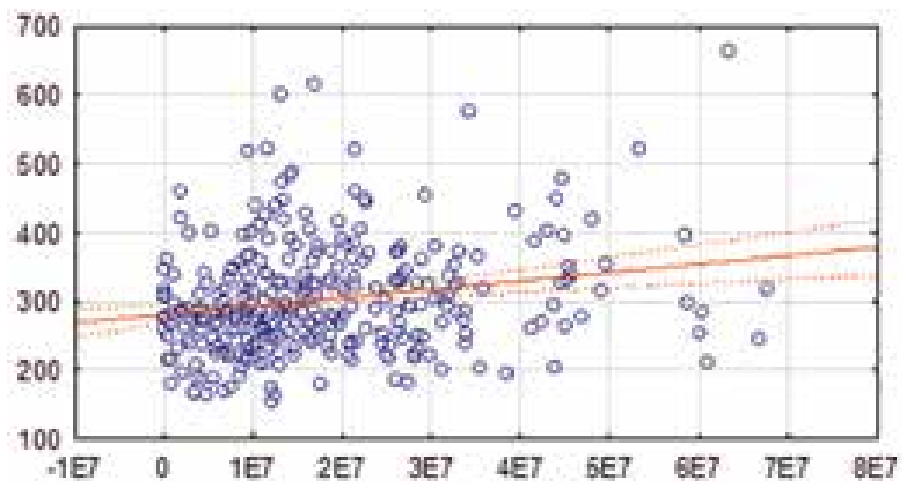

$\mathrm{X}$ - total obligations [pln], Y - own-source revenue [pln], correlation ' $r$ ' $=0.20823$

Source: Own elaboration on the basis of Table 2.

Diagram 3. Scatter plot: total obligations vs. own-source revenues in 2016

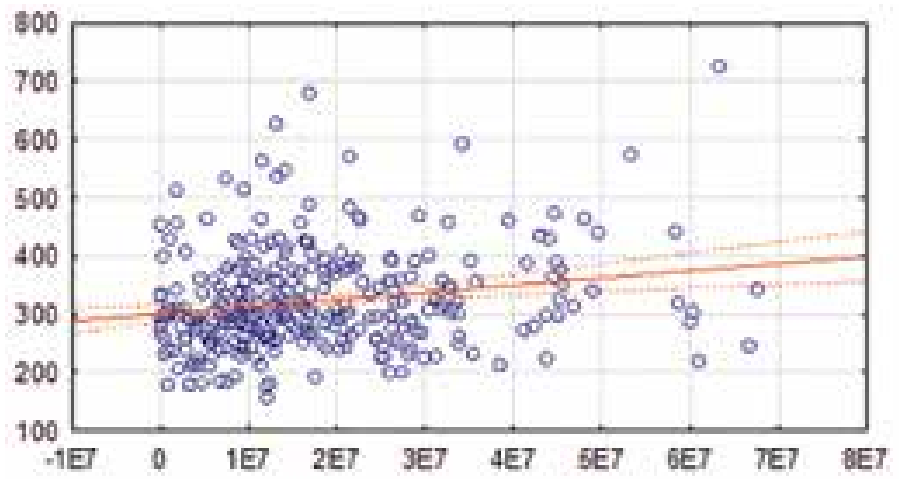

$\mathrm{X}$ - total obligations [pln], Y - own-source revenue [pln], correlation ' $r$ ' $=0.19740$

Source: Own elaboration on the basis of Table 2.

Diagram 4. Scatter plot: total obligations vs. total expenditure in 2014

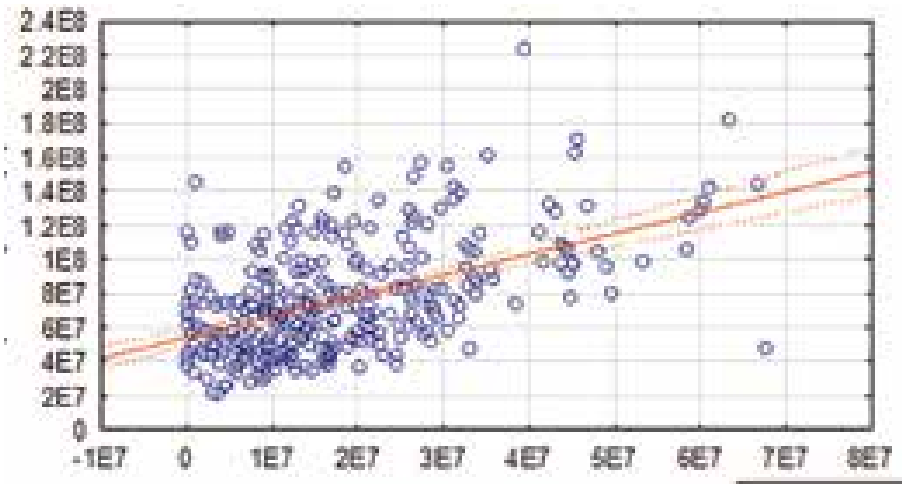

$\mathrm{X}$ - total obligation [pln], $\mathrm{Y}$ - total expenditure [pln], correlation ' $\mathrm{r}$ ' $=0.51801$

Source: Own elaboration on the basis of Table 2 . 
Diagram 5. Scatter plot: total obligations vs. total expenditure in 2015

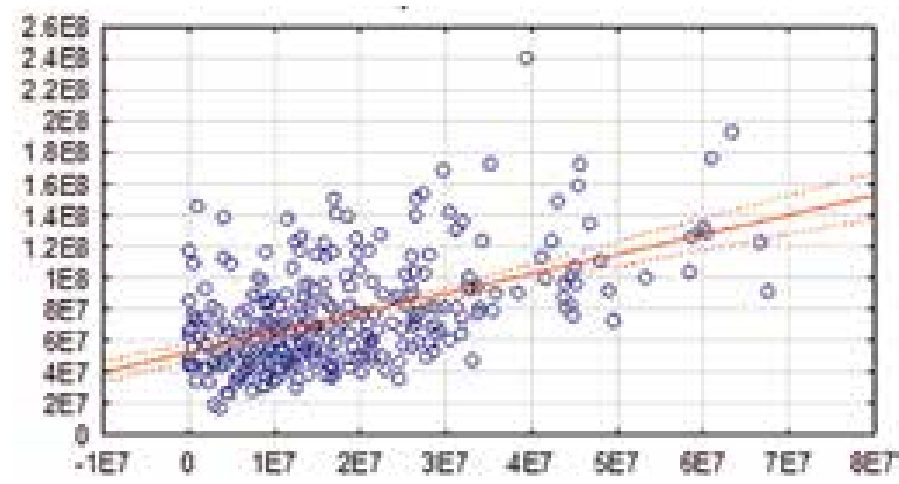

$\mathrm{X}$ - total obligation [pln], $\mathrm{Y}$ - total expenditure [pln], correlation ' $r$ ' $=0.51728$ Source: Own elaboration on the basis of Table 2.

Diagram 6. Scatter plot: total obligations vs. total expenditure in 2016

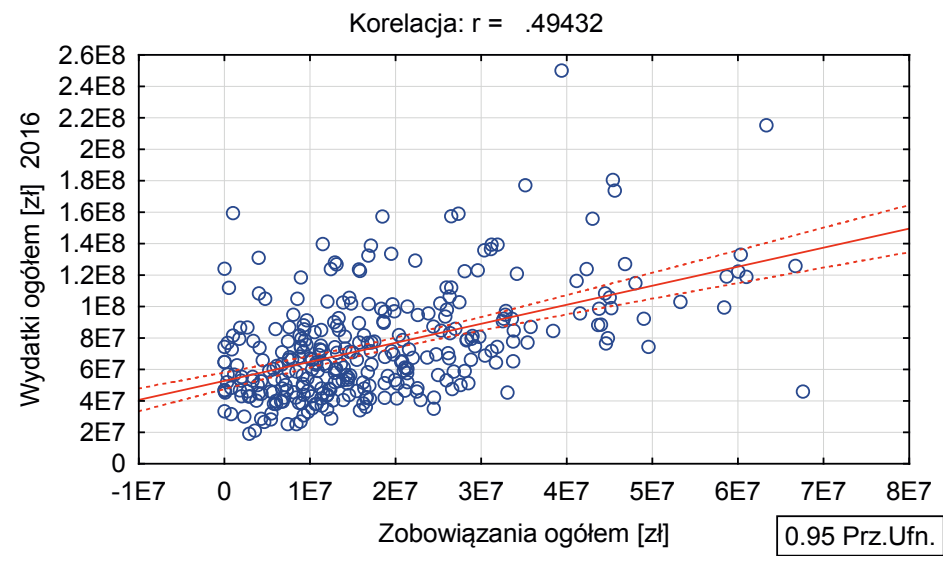

$\mathrm{X}$ - total obligation [pln], Y - total expenditure [pln], correlation ' $r$ ' $=0.49432$

Source: Own elaboration on the basis of Table 2.

Diagram 7. Scatter plot: total obligations vs. assets investment expenditure in 2014

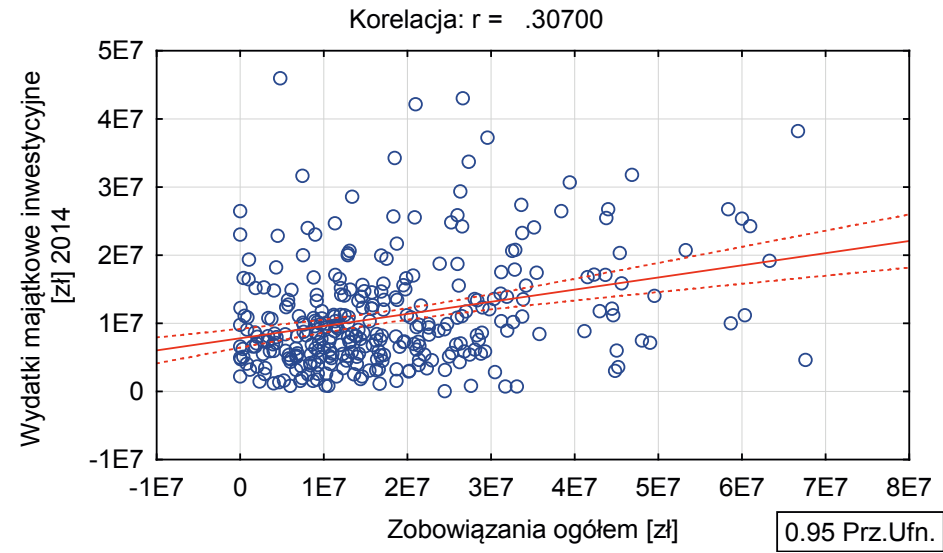

$\mathrm{X}$ - total obligations [pln], Y - assets investment expenditures [pln], correlation ' $r$ ' $=0.30700$

Source: Own elaboration on the basis of Table 2. 
Diagram 8. Scatter plot: total obligations vs. assets investment expenditure in 2015

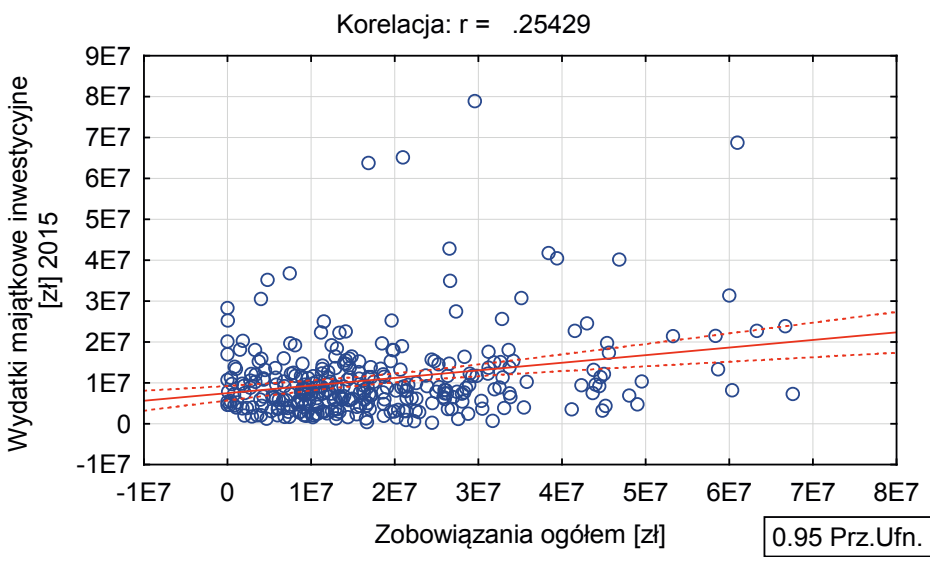

$\mathrm{X}$ - total obligations [pln], Y - assets investment expenditures [pln], correlation ' $r$ ' $=0.25429$

Source: Own elaboration on the basis of Table 2.

Diagram 9. Scatter plot: total obligations vs. assets investment expenditure in 2016

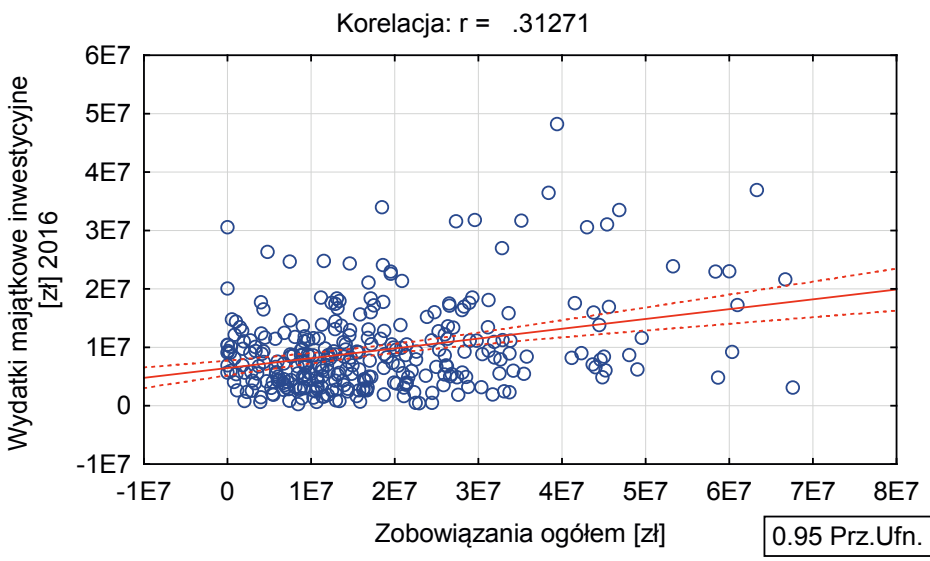

$\mathrm{X}$ - total obligations [pln], Y - assets investment expenditures [pln], correlation ' $r$ ' $=0.31271$

Source: Own elaboration on the basis of Table 2.

The next analysis examined the interdependence occurring in districts (powiat) between total district obligations per resident and aggregates per resident, such as total revenue, ownsource revenue, total expenditures and investment expenditures. To facilitate this examination, Spearman's rank-order correlation coefficient was applied.

Table 3. Spearman's rank-order correlation

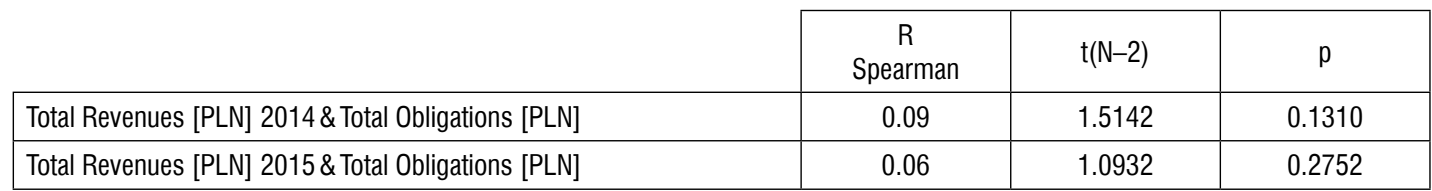




\begin{tabular}{|c|c|c|c|}
\hline & $\begin{array}{c}\mathrm{R} \\
\text { Spearman }\end{array}$ & $\mathrm{t}(\mathrm{N}-2)$ & $\mathrm{p}$ \\
\hline Total Revenues [PLN] 2016\& Total Obligations [PLN] & 0.09 & 1.5313 & 0.1267 \\
\hline Own-Source Revenue [PLN] 2014\& Total Obligations [PLN] & 0.20 & 3.5758 & 0.0004 \\
\hline Own-Source Revenue [PLN] 2015\& Total Obligations [PLN] & 0.21 & 3.7638 & 0.0002 \\
\hline Own-Source Revenue [PLN] 2016\& Total Obligations [PLN] & 0.20 & 3.6113 & 0.0004 \\
\hline Total Expenditure [PLN] 2014\& Total Obligations [PLN] & 0.47 & 9.4483 & 0.0000 \\
\hline Total Expenditure [PLN] 2015\& Total Obligations [PLN] & 0.47 & 9.3028 & 0.0000 \\
\hline Total Expenditure [PLN] 2016\& Total Obligations [PLN] & 0.46 & 9.1160 & 0.0000 \\
\hline Assets Investment Expenditures [PLN] 2014 \& Total Obligations [PLN] & 0.27 & 4.9236 & 0.0000 \\
\hline Assets Investment Expenditures [PLN] 2015\& Total Obligations [PLN] & 0.17 & 2.9935 & 0.0030 \\
\hline Assets Investment Expenditures [PLN] 2016\& Total Obligations [PLN] & 0.20 & 3.5828 & 0.0004 \\
\hline
\end{tabular}

Source: Own elaboration on the basis of Information re: LGU Budget Implementation Statements 2014-2016, Poland's Ministry of Finance, http://www.mf.gov.pl/ministerstwo-finansow/dzialalnosc/finanse-publiczne/budzety-jednostek-samorzadu-terytorialnego/sprawozdania-budzetowe/

The above analysis enabled confirmation in practically all pairs $(\mathrm{p}<0.05)$ - with the exception of total revenues - of significant, positive correlations (weak and average).

Table 4. Spearman's rank-order correlation

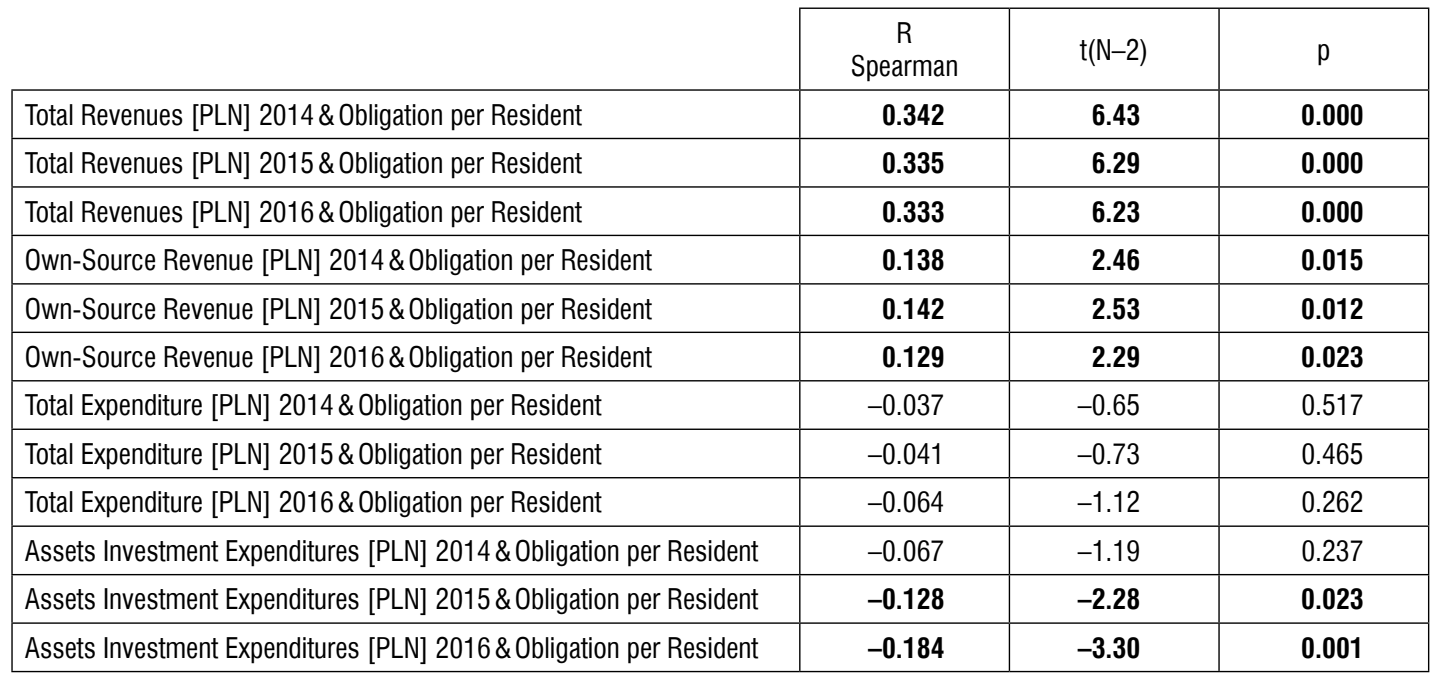

Source: Own elaboration on the basis of Information re: LGU Budget Implementation Statements 2014-2016, Poland's Ministry of Finance. Retrieved from: http://www.mf.gov.pl/ministerstwo-finansow/dzialalnosc/finanse-publiczne/budzety-jednostek-samorzadu-terytorialnego/sprawozdania-budzetowe/

The analysis of Table 4 allows the conclusion - with the exception of total expenditure and investment expenditure of 2014 - of significant, positive correlations albeit weak and average. Positive correlation was confirmed between total revenues for the examined years and obligations per resident - $\mathrm{R}(0.33-0.34)$ average correlation, and a weak positive correlation between own-source revenue and obligations per resident. 


\section{Summary}

Properly generated budget implementation statements enable fulfilling the regulation requirements of the law, and as such, they produce the basis to formulate observations regarding financial management in local governments. The information contained in the annual statements is an essential source of credible data enabling comparisons with regard to levels of revenue or expenditures in various periods, and consequently assist future budgets.

The results of this study show that the obligation levels in the period 2014-2016 had a significant, positive statistical correlation with own-source revenues, assets investment expenditures and total expenditures. No significant statistical correlation was found between obligation levels and descriptive variables referring to revenue and expenditure dynamics. Spearman's rank-order correlation enabled confirmation of the positive correlations between total revenues in the selected years and obligations per resident, and also weak, positive correlations between own-source revenues and obligations per resident.

\section{References}

1. Adamek-Hyska D., 2016. Bilans i sprawozdanie z wykonania budżetu w kształtowaniu obrazu sytuacji finansowej jednostki samorządu terytorialnego. Studia Ekonomiczne. Zeszyty Naukowe Uniwersytetu Ekonomicznego w Katowicach, No. 285/2016, pp. 28-38.

2. Błaszko A., et al., 2015. Zamknięcie roku w jednostkach sfery finansów publicznych. Warszawa: Wolters Kluwer, p. 164.

3. Bogucka-Felczak M., 2017. Potencjał dochodów podatkowych jednostek samorządu terytorialnego - wybrane problemy, A. Kołodziejska, A. Korzeniowska-Polak, (et al.) Zarządzanie publiczne. Funkcjonowanie jednostek samorządu terytorialnego w aspekcie wielowymiarowym. Przedsiębiorczość i Zarządzanie, Vol. XVIII, Book 2, Part I, pp. 77-90.

4. Filipiak B., 2017. Ocena wydatków inwestycyjnych jednostek samorządu terytorialnego szczebla wojewódzkiego w świetle ryzyka realizacji zadań. Annals of Maria Curie-Skłodowska University, Sectio H, Oeconomia, Vol. LI 4, pp. 95-105.

5. Kończak G., Trzpiot G., 2014. Metody statystyczne z wykorzystaniem programów komputerowych. Katowice: Wydawnictwo Uniwersytetu Ekonomicznego w Katowicach, pp. 239-244.

6. Mastalski R., Fojcik-Mastalska E., 2013. Prawo finansowe, 2nd ed. Warszawa: Wolters Kluwer, p. 479.

7. Miemiec W., Sawicka K., Miemiec M., 2013. Prawo finansów publicznych sektora samorządowego. Warszawa: Wolters Kluwer, p. 242.

8. Owsiak S., 2002. Teoretyczne podstawy wykorzystania budżetu w zarzadzaniu jednostkami samorzadu terytorialnego. In: S. Owsiak (Ed.), Budżet władz lokalnych.Narzędzie zarządzania. Warszawa: Polskie Wydawnictwo Ekonomiczne, p. 32. 
9. Staszel A., 2016. Narzędzia analizy finansowej w jednostkach samorządu terytorialnego. Zeszyty Naukowe, Kraków University of Economics, No. 10(958), pp. 65-80.

10. Winiarska K., Kaczurak-Kozak M., 2013. Rachunkowość budżetowa, 4th ed. Warszawa: Wolters Kluwer, p. 112.

11. Wojciechowski J., Wpływ zadłużenia na kształtowanie się dochodów oraz wydatków gmin miejskich województwa kujawsko-pomorskiego w latach 1993-2006, Rocznik Żyrardowski, Vol. 6. Retrieved from: http://mazowsze.hist.pl/files/Rocznik_Zyrardowski/PDF_bez_tytulowych/ Rocznik_Zyrardowski-r2008-t6/Rocznik_Zyrardowski-r2008-t6-s165-200/Rocznik_Zyrardowski-r2008-t6-s165-200.pdf, [accessed: 8.1.2018].

\section{Legal and strategic documents}

1. Constitution of the Republic of Poland of April 2, 1997, Dz. U. 1997, [Journal of Laws], No. 78, Position 483 as amended.

2. Law of August 27, 2009 pertaining to Public Finance, Dz. U. 2017 [Journal of Laws], No. 2077 as amended.

3. Law of November 13, 2003 pertaining to local government unit revenues, Dz. U. 2017 [Journal of Laws], Position 1453 as amended.

4. Law of June 5, 1998 regarding District Government, Dz. U. 2017, [Journal of Laws], Item 1868.

5. Law of June 5, 1998 regarding Voivodship Government, Dz. U. 2017 [Journal of Laws], Item 2096.

6. Law of March 8, 1990 regarding Commune Government, Dz. U. 2017 [Journal of Laws], Item 1875.

7. LGU Budget Implementation Statements 2014-2016, Poland's Ministry of Finance. Retrieved from: http://www.mf.gov.pl/ministerstwo-finansow/dzialalnosc/finanse-publiczne/budzetyjednostek-samorzadu-terytorialnego/sprawozdania-budzetowe/ [accessed: 06.02.2018]. 